\title{
Spectrophotometric Quantification of Anti-inflammatory Drugs by Application of Chromogenic Reagents
}

\author{
Anti-enflamatuvar Illaçların Kromojenik Reaktifler Kullanılarak \\ Spektrofotometrik Miktar Tayinleri
}

\author{
(D) Panikumar Durga ANUMOLU*, (D) Sunitha GURRALA, (D) Archana GELLABOINA, (D) Divya Gayathri MANGIPUDI, (D) Sahitya MENKANA, \\ (D) Rajesh CHAKKA \\ Osmania University, Gokaraju Rangaraju College of Pharmacy, Department of Pharmaceutical Analysis and Quality Assurance, Hyderabad, Telangana \\ State, India
}

\begin{abstract}
Objectives: Simple, specific, accurate, precise, sensitive, and cost effective spectrophotometric methods were developed and validated for quantification of the drugs lornoxicam (LOR) and mesalamine (MES) in pure form and in pharmaceutical formulations.

Materials and Methods: A Shimadzu UV-1800 double-beam UV-Visible spectrophotometer having a spectral bandwidth of $0.1 \mathrm{~nm}$ with wavelength accuracy $\pm 0.1 \mathrm{~nm}$ with a pair of $1 \mathrm{~cm}$ path length matched quartz cells was used to measure the absorbance of the resulting solution.

Method I was used for the quantification of LOR, based on measurement of the absorbance of bluish green chromogen complex at $760 \mathrm{~nm}$, which is formed by the reaction of LOR with ferric chloride and potassium ferricyanide (redox technique). Method II was used for the quantification of MES, based on measurement of the absorbance of yellow chromogen at $400 \mathrm{~nm}$, which is formed by the condensation reaction of the primary amino group of MES with salicylaldehyde reagent (SA) (Schiff base formation).

Results: Both methods obeyed Beer's law in the concentration range of $0.5-4.5 \mu \mathrm{g} / \mathrm{mL}$ and $0.2-1.7 \mu \mathrm{g} / \mathrm{mL}$ with good correlation coefficients of 0.9974 and 0.998 for methods I and II, respectively.

Conclusion: The developed method is simple, sensitive, and specific, which was validated statistically as per ICH guidelines, and can be used in the routine analysis of LOR and MES in pharmaceutical dosage forms.
\end{abstract}

Key words: Ferric chloride, lornoxicam, mesalamine, salicylaldehyde reagent, visible spectrophotometry

ÖZ

Amaç: Lornoksikam (LOR) ve mesalaminin (MES) hem saf formda hemde farmasötik formülasyonlarda tayini için basit, spesifik, doğru, duyarlı ve düşük maliyetli spektrofotometrik yöntemler, geliştirmek ve valide etmektir.

Gereç ve Yöntemler: Elde edilen çözeltilerin absorbansları Shimadzu UV-1800 çift ışınlı spektrofotometrede 0,1 nm spektral bant genişliği ve $\pm 0,1$ nm hassasiyetle $1 \mathrm{~cm}$ 'lik kuvars küvetler kullanılarak ölçüldü.

Bulgular: Metot I, LOR'nin demir III klorür ve potasyum ferrisiyanür (redoks tekniği) ile reaksiyonu sonucu oluşan mavimsi yeşil renkli kromojen kompleksinin absorbansının 760 nm'de ölçümüne dayanan yöntemdir. Metot II, MES'nin primer amino grubunun salisilaldehit reaktifi (SA) (Schiff baz oluşumu) ile kondensasyon reaksiyonundan oluşan sarı renkli kromojenin absorbansının 400 nm'de ölçümüne dayanan yöntemdir. Metot I ve II için; her iki yöntemde de, sırasıyla 0,5-4,5 $\mu \mathrm{g} / \mathrm{mL}$ ve 0,2-1,7 $\mu \mathrm{g} / \mathrm{mL}$ 'lik konsantrasyon aralıklarında, Beer yasasına sırasıyla 0,9974 ve 0,9980'lık korelasyon katsayıları ile iyi bir uygunluk göstermişlerdir.

Sonuç: Geliștirilen yöntemler; LOR ve MES'nin farmasötik dozaj formlarının rutin analizinde kullanılabilecek ve ICH yönergelerine göre valide edilmiş basit, hassas ve spesifik yöntemlerdir.

Anahtar kelimeler: Demir III klorür, lornoksikam, mesalamin, salisilaldehit reaktifi, görünür spektrofotometri

*Correspondence: E-mail: panindrapharma@yahoo.co.in, Phone: +9010014734 ORCID: orcid.org/0000-0001-5010-7488

Received: 23.04.2018, Accepted: 27.07.2018

๑Turk J Pharm Sci, Published by Galenos Publishing House. 


\section{INTRODUCTION}

Lornoxicam (LOR) has the IUPAC name 6-chloro-4-hydroxy2-methyl-N-2-pyridinyl-2H-thieno [2, 3-e]-1,2-thiazine-3carboximide 1,1-dioxide. It belongs to the class of oxicams and it is a nonsteroidal anti-inflammatory drug with analgesic properties (Figure 1). Mesalamine (MES) has the IUPAC name 5-amino-2-hydroxy benzoic acid (Figure 2). It is an antiinflammatory drug used to treat inflammation of the digestive tract (Crohn's disease) and mild to moderate ulcerative colitis.

A literature survey revealed that numerous analytical methods have been published for the analysis of both LOR and MES by ultraviolet (UV) spectrophotometric and high performance liquid chromatography (HPLC) methods. ${ }^{2-18}$ Most of the reported procedures are not simple for routine analysis and require expensive or sophisticated instruments. Hence, it is always required to develop simple, fast, and inexpensive analytical methods that can be readily adopted for routine analysis at a relatively low cost for the different requirements of analytical problems.

Visible spectrophotometry, because of its simplicity and cost effectiveness, sensitivity and selectivity, fair accuracy, precision, and easy access in most quality control laboratories, has remained competitive in the area of chromatographic techniques for pharmaceutical analysis. Visible spectrophotometric methods based on diverse reactions have been reported for the determination of LOR and MES in pharmaceutical dosage forms. ${ }^{19,20}$ However, most of the reported visible spectrophotometric methods suffer from disadvantages like narrow range of determination, poor sensitivity, and temperature and $\mathrm{pH}$ maintenance. In the present work, two simple and sensitive extraction-free spectrophotometric methods based on the redox reaction and

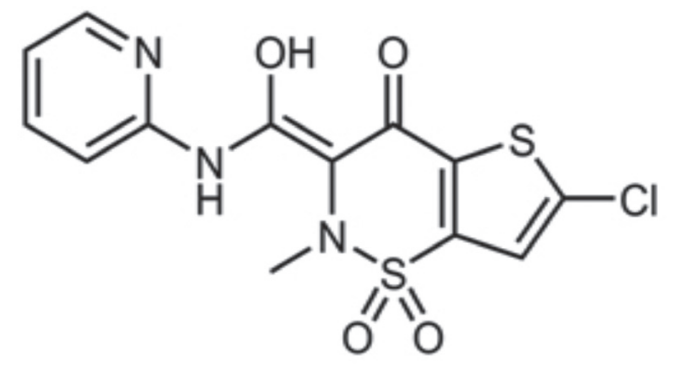

Figure 1. Structure of lornoxicam

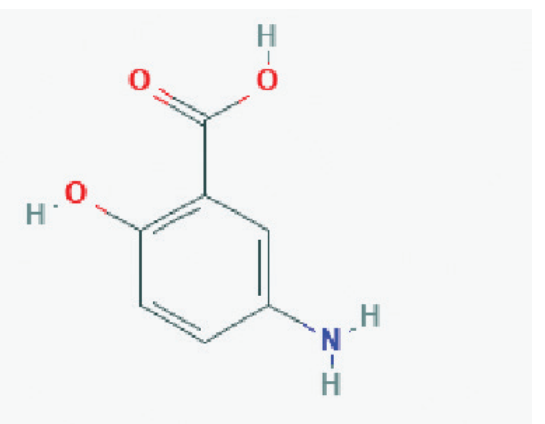

Figure 2. Structure of mesalamine condensation reaction are proposed for the determination of LOR and MES in bulk drug and pharmaceutical dosage forms.

\section{MATERIALS AND METHODS}

\section{Preparation of reagents and solutions}

Ferric chloride solution ( $3 \% \mathrm{w} / \mathrm{v}$ ) was prepared by dissolving 3 $\mathrm{g}$ in $100 \mathrm{~mL}$ of $0.1 \mathrm{~N}$ hydrochloric acid. Potassium ferricyanide $(0.3 \% \mathrm{w} / \mathrm{v})$ was prepared by dissolving $300 \mathrm{mg}$ in $100 \mathrm{~mL}$ of distilled water. Salicylaldehyde reagent $(5 \% \mathrm{v} / \mathrm{v})$ was prepared by diluting $0.5 \mathrm{~mL}$ to $10 \mathrm{~mL}$ using ethanol.

LOR stock solution was prepared by weighing $10.0 \mathrm{mg}$ of LOR and dissolving it in a few milliliters of $0.01 \mathrm{M} \mathrm{NaOH}$ and the volume was made up to $100.0 \mathrm{~mL}$ with $0.01 \mathrm{M} \mathrm{NaOH}$ to acquire $100 \mathrm{\mu g} / \mathrm{mL}$ solution. Further dilutions were made from stock solution to obtain the required concentration for method I.

MES stock solution was prepared by weighing $10.0 \mathrm{mg}$ of MES and dissolving it in a few milliliters of $0.1 \mathrm{M} \mathrm{NaOH}$ and the volume was made up to $100.0 \mathrm{~mL}$ with $0.1 \mathrm{M} \mathrm{NaOH}$ to acquire $100 \mathrm{\mu g} / \mathrm{mL}$ solution. Further dilutions were made from stock solution to obtain the required concentration for method II.

\section{Preparation of sample solutions}

\section{Redox-complexation method}

Aliquots of standard drug solution of LOR ranging from 0.05 to $0.45 \mathrm{~mL}$ were taken into a series of $10.0-\mathrm{mL}$ volumetric flasks. Then $0.5 \mathrm{~mL}$ of $3 \% \mathrm{w} / \mathrm{v}$ ferric chloride, $0.5 \mathrm{~mL}$ of $0.3 \% \mathrm{w} / \mathrm{v}$ potassium ferricyanide, and $0.5 \mathrm{~mL}$ of $1 \mathrm{~N}$ hydrochloric acid were added. The volume was made up to the mark with water to prepare a series of standard solutions containing 0.5-4.5 $\mu \mathrm{g} / \mathrm{mL}$. The solutions were kept aside for $30 \mathrm{~min}$ and later the absorbance was measured at $760 \mathrm{~nm}$ against the corresponding reagent blank.

\section{Condensation method}

Aliquots of standard drug solution of MES ranging from 0.02 to $0.17 \mathrm{~mL}$ were prepared in a series of $10.0 \mathrm{~mL}$ volumetric flasks. To this $1 \mathrm{~mL}$ of $5 \% \mathrm{v} / \mathrm{v}$ salicylaldehyde was added. The volume was then made up to the mark with ethanol to prepare a series of standard solutions containing $0.2-1.7 \mu \mathrm{g} / \mathrm{mL}$. The complete color development was attained after $45 \mathrm{~min}$. Then the absorbance of the colored chromogen was measured at $400 \mathrm{~nm}$ against the corresponding reagent blank.

In both methods (I and II), calibration curves were prepared and the linearity in pure solution was checked over concentration of $0.5-4.5 \mu \mathrm{g} / \mathrm{mL}$ for LOR and $0.2-1.7 \mu \mathrm{g} / \mathrm{mL}$ for MES. The relative standard deviation (RSD) and correlation coefficient of the standard curve were calculated.

\section{Assay of pharmaceutical dosage form}

\section{Method I}

The contents of 20 tablets (Lornoxi 4 and 8; Lorsaid 4 and 8 ) were weighed and powdered. The equivalent quantity to $4 \mathrm{mg}$ of active ingredient was dissolved in $0.01 \mathrm{~N} \mathrm{NaOH}$ and the volume was made up to $10.0 \mathrm{~mL}$ and was filtered using Whatman filter paper. Appropriate dilutions of the prepared 
solution were made to prepare its working solution and the procedures under linearity were followed. The absorbance of the colored chromogen was measured at $760 \mathrm{~nm}$ against the corresponding reagent blank.

\section{Method II}

The contents of 20 tablets (Mesacol $400 \mathrm{mg}$ ) were weighed and powdered. The equivalent quantity to $10 \mathrm{mg}$ of active ingredient was dissolved in $0.1 \mathrm{~N} \mathrm{NaOH}$ and the volume was made up to $10.0 \mathrm{~mL}$ and was filtered using Whatman filter paper. Appropriate dilutions of the prepared solution were made to prepare its working solution and the procedures under linearity were followed. The absorbance of the colored chromogen was measured at $400 \mathrm{~nm}$ against the corresponding reagent blank.

\section{RESULTS AND DISCUSSION}

To attain a sensitive and specific photometric method for quantification of LOR and MES, distinct experimental conditions were investigated such as concentration of chromogenic agent, strength of the medium, concentration of oxidizing agent, temperature conditions, and time for stability of the chromogenic complex.

\section{Redox-complexation method}

LOR exhibits a reducing property due to the presence of functional moieties vulnerable to oxidation selectively with oxidizing agents such as ferric chloride. Under controlled experimental conditions when treated with a known excess amount of oxidant, LOR undergoes oxidation, giving products of oxidation (inclusive of reduced form of oxidant Fe(II) from Fe(III) besides unreacted oxidant. It is possible to estimate the drug content colorimetrically, which is equivalent to either reduced oxidant or reduced form of oxidant formed. The reduced form of Fe(III), i.e. Fe(II), has a tendency to give a blue green complex on treatment with potassium ferricyanide. The absorbance of the bluish green complex formed was measured at $760 \mathrm{~nm}$ (Scheme 1).

\section{Condensation method}

MES undergoes a condensation reaction with salicylaldehyde giving a yellow Schiff base product. MES contains a primary amine group, which reacts with an active carbonyl group in salicylaldehyde forming Schiff bases [compounds containing an imine or azomethine group $(-\mathrm{RCH}=\mathrm{N}-)$ ] of stable yellow exhibiting absorption maxima at $400 \mathrm{~nm}$ and the reaction proceeds in ethanol (Scheme 2).

\section{Method validation}

Validation of the analytical method was carried out according to International Conference on Harmonisation (ICH) recommendations [ICH, Q1A (R2), 2005]. ${ }^{21}$

\section{Linearity and range}

The linearity of an analytical method is its ability to elicit test results that are directly or by a well-defined mathematical transformation proportional to the concentration of analyte in samples within a given range. The calibration graph showed that a linear response was obtained over the range of concentrations used in the assay procedure. The linearity ranges are $0.5-4.5 \mu \mathrm{g} / \mathrm{mL}$ and $0.2-1.7 \mu \mathrm{g} / \mathrm{mL}$ for methods I and II respectively (Figures 3 and 4). The correlation coefficients of drugs in methods I and II were 0.9974 and 0.998, respectively. These data clearly demonstrate that the developed methods have adequate sensitivity to the concentration of the analytes in the sample. The optical characteristics of both methods such as absorption maxima, Beer's law limits, molar absorptivity, Sandell's sensitivity, and regression equation are reported in Table 1.

\section{Precision}

Precision of the method was determined by intraday and interday precision as per ICH guidelines. Intraday precision was investigated by preparing six replicate sample solutions on the same day. Interday precision was assessed by analyzing newly prepared sample solutions in triplicate over three consecutive<smiles>CN1/C(=C(\O)Nc2ccccn2)C(=O)c2sc(Cl)cc2S1(=O)=O</smiles>

lornoxicam<smiles>CN1C(C(=O)Nc2ccccn2)Cc2sc(Cl)cc2S1(=O)=O</smiles>

Oxidation product of lornoxicam

\section{$+\mathrm{Fe}(\mathrm{II})+$ Unreacted Fe(III)}

\section{$\mathrm{Fe}(\mathrm{II})+\mathrm{K}_{3} \mathrm{Fe}(\mathrm{III})(\mathrm{CN})_{6}$}

$\mathrm{K}_{3} \mathrm{Fe}^{+3}\left[\mathrm{Fe}^{+2}(\mathrm{CN})_{6}\right]$

Coloured complex

Scheme 1. Reaction mechanism of LOR with potassium ferricyanide in the presence of ferric chloride 
days. The obtained RSD \% was within the acceptable range. The results of this study are summarized in Table 2 .

\section{Accuracy}

Accuracy of the methods was assured by applying the standard addition technique where good percentage recoveries were obtained, confirming the accuracy of the proposed methods. The average percentage recovery and RSD \% were statistically calculated. The \% recovery values for both the methods are shown in Table 3.

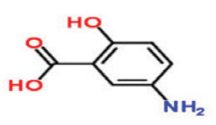

mesalamine<smiles>O=Cc1ccccc1O</smiles>
salicylaldehyde

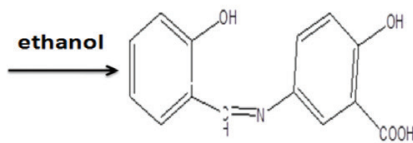

Scheme 2. Reaction mechanism of MES with salicylaldehyde MES: Mesalamine

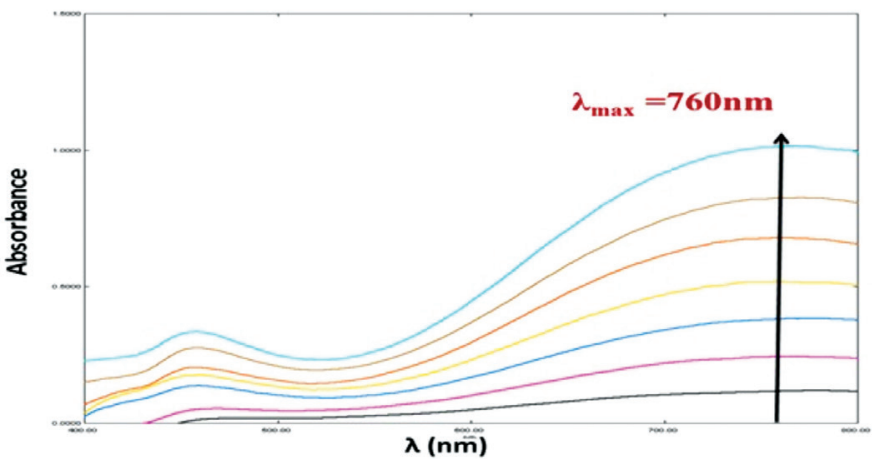

Figure 3. Absorption spectra of lornoxicam with potassium ferricyanide and ferric chloride

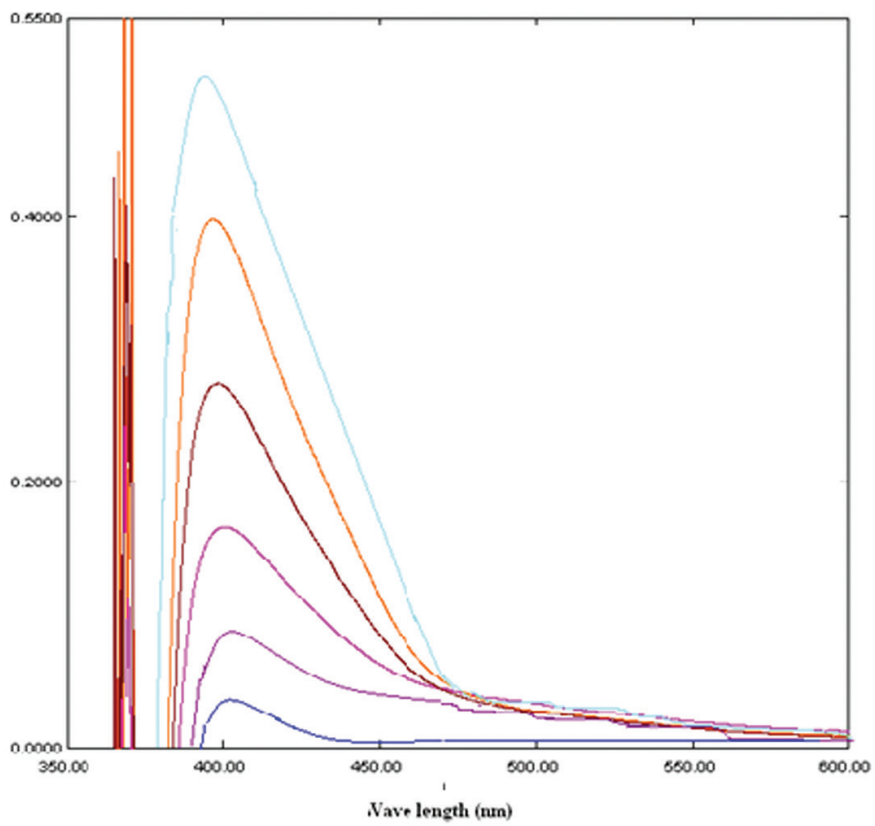

Figure 4. Absorption spectra of mesalamine with salicylaldehyde
Limit of detection (LOD) and limit of quantification (LOQ)

The LOD and LOQ for methods I and II by the proposed method were determined using calibration standards. LOD and LOQ were calculated by using $3.3 \mathrm{\sigma} / \mathrm{s}$ and $10 \mathrm{\sigma} / \mathrm{s}$, respectively, where $s$ is the slope of the calibration curve and $\sigma$ is the standard deviation of the $y$ intercept of the regression equation. The LOD and LOQ were $0.0094 \mu \mathrm{g} / \mathrm{mL}$ and $0.0154 \mu \mathrm{g} / \mathrm{mL}$ for method I and $0.0129 \mu \mathrm{g} / \mathrm{mL}$ and $0.0392 \mu \mathrm{g} / \mathrm{mL}$ for method II, respectively.

Application of the proposed method (analysis of commercially available formulations)

The proposed method was successfully applied to the analysis of both the drugs in their respective pharmaceutical formulations. The results obtained were in good agreement with the label claim as concluded from the satisfactory values of \% assay and $\%$ RSD shown in Table 4. The assay values were compared with

\begin{tabular}{|c|c|c|}
\hline Parameters & Method I & Method II \\
\hline Absorption wavelength (nm) & 760 & 400 \\
\hline Beer's law range $(\mu \mathrm{g} / \mathrm{mL})$ & $0.5-4.5$ & $0.2-1.7$ \\
\hline $\begin{array}{l}\text { Molar absorptivity } \\
(\mathrm{Lcm} / \mathrm{mol})\end{array}$ & $1.1 \times 10^{4}$ & $1.2 \times 10^{4}$ \\
\hline $\begin{array}{l}\text { Sandell's sensitivity } \\
\left(\mu \mathrm{g} / \mathrm{cm}^{2}\right)\end{array}$ & 0.0038 & 0.0048 \\
\hline Limit of detection $(\mu \mathrm{g} / \mathrm{mL})$ & 0.0094 & 0.0129 \\
\hline $\begin{array}{l}\text { Limit of quantification } \\
(\mu g / m L)\end{array}$ & 0.0154 & 0.0392 \\
\hline Correlation coefficient $\left(r^{2}\right)$ & 0.9974 & 0.9984 \\
\hline Slope (m) & 0.2343 & 0.306 \\
\hline Intercept (c) & 0.0083 & 0.011 \\
\hline Regression equation & $Y=0.2343 x+0.0083$ & $Y=0.306 x-0.011$ \\
\hline
\end{tabular}

Table 2. Precision for methods I and II

\begin{tabular}{llll} 
& Intraday precision & Interday precision \\
\hline Concentration & Concentration & $\% \mathrm{RSD}^{\mathrm{a}}$ & Concentration $\% \mathrm{RSD}^{\mathrm{a}}$ \\
$(\mu \mathrm{g} / \mathrm{mL})$ & estimated & & estimated \\
& $(\mu \mathrm{g} / \mathrm{mL})$ & $(\mathrm{ng} / \mathrm{mL})$ \\
& $\mathrm{AM} \pm \mathrm{SD}^{*}$ & $\mathrm{AM} \pm \mathrm{SD}^{*}$ & \\
\end{tabular}

Precision values for method I

\begin{tabular}{|c|c|c|c|c|}
\hline 0.5 & $0.524 \pm 0.002$ & 0.381 & $0.512 \pm 0.0012$ & 0.234 \\
\hline 2.5 & $2.428 \pm 0.004$ & 0.164 & $2.524 \pm 0.0045$ & 0.178 \\
\hline 4.5 & $4.621 \pm 0.001$ & 0.021 & $4.545 \pm 0.0026$ & 0.057 \\
\hline \multicolumn{5}{|c|}{ Precision values for method II } \\
\hline 0.5 & $0.501 \pm 0.004$ & 0.279 & $0.505 \pm 0.0012$ & 0.237 \\
\hline 1.1 & $1.14 \pm 0.0028$ & 0.245 & $1.12 \pm 0.0032$ & 0.285 \\
\hline 1.7 & $1.73 \pm 0.0056$ & 0.323 & $1.72 \pm 0.0026$ & 0.151 \\
\hline
\end{tabular}

*Mean value of 6 determinations. Relative standard deviation (\%). RSD: Relative standard deviation, SD: Standard deviation 
Table 3. Accuracy studies for methods I and II

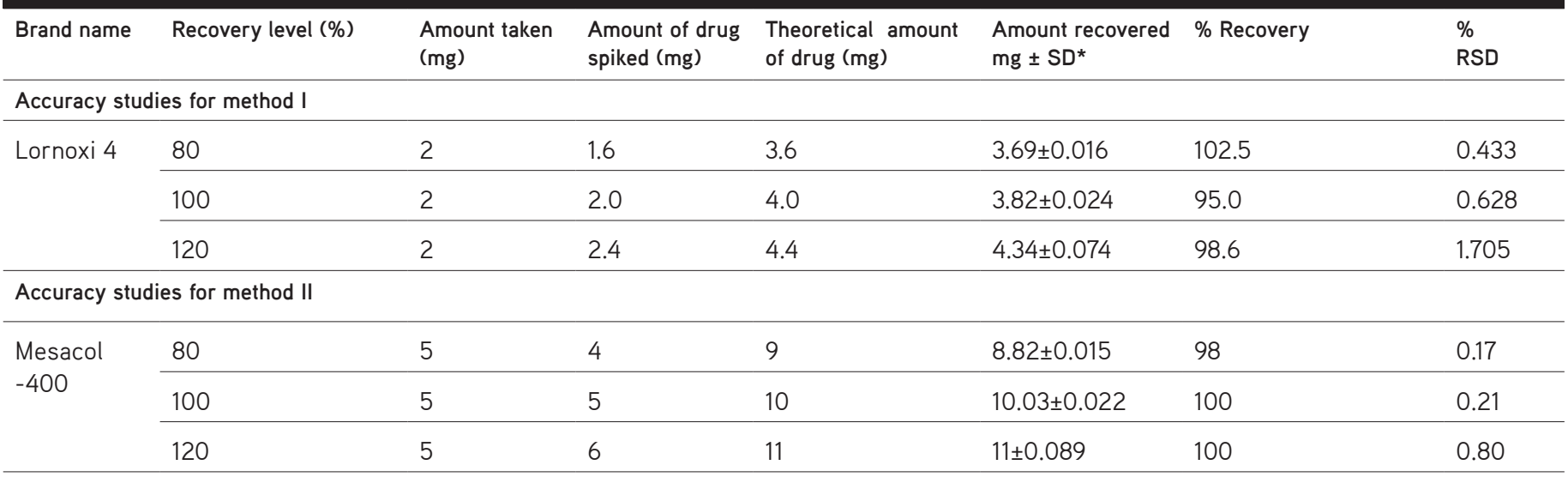

RSD: Relative standard deviation, SD: Standard deviation

Table 4. Assay of methods I and II

\begin{tabular}{|c|c|c|c|c|c|c|}
\hline Formulation & Label claim (mg) & Amount found ( $\mathrm{mg}$ & & & $\%$ Assay & $\%$ RSD \\
\hline & & Proposed method & Reference method ${ }^{6,15}$ & T-test value & & \\
\hline Lornoxi 4 & 4 & $3.92 \pm 0.015$ & $4.02 \pm 0.008$ & 0.882 & 99 & 0.377 \\
\hline Lornoxi 8 & 8 & $7.99 \pm 0.062$ & $7.95 \pm 0.011$ & 0.21 & 99.8 & 0.775 \\
\hline Lorsaid 4 & 4 & $3.96 \pm 0.045$ & $3.93 \pm 0.012$ & 0.09 & 99 & 0.303 \\
\hline Lorsaid 8 & 8 & $7.97 \pm 0.012$ & $8.04 \pm 0.017$ & 0.5 & 99.8 & 0.150 \\
\hline
\end{tabular}

* Mean of three determinations.

RSD: Relative standard deviation, SD: Standard deviation

reference method values using Student's t-test. The calculated values were less than the tabulated $t$-value $(t=2.571$ at $p \leq 0.05)$, which revealed that there is no significant difference between the proposed method and the reference method (similarity of the methods).

\section{CONCLUSION}

The contemplated method was simple, sensitive, accurate, and precise for the quantification of LOR and MES in pharmaceutical dosage forms. The assay values were in good concord with their respective dosage form. The developed spectrophotometric methods were found to be enhanced because of their specificity, sensitivity, no extraction procedures, time saving nature, cost effectiveness, and involving very simple procedures. Besides the simplicity and sensitivity of the procedures, the relative inexpensive apparatus and cost effective reagents demonstrate their advantageous characteristics when compared to HPLC techniques. These advantages indicate that the contemplated method can be routinely used in quality control for analysis of LOR and MES in pharmaceutical dosage forms.

\section{ACKNOWLEDGEMENTS}

The authors are sincerely thankful to the management and Prof. C.V.S. Subramanyam, Principal, Gokaraju Rangaraju College of Pharmacy, for supporting this work.
Conflict of Interest: No conflict of interest was declared by the authors.

\section{REFERENCES}

1. Maryadale J.O., NF. USP. 2006;679-680.

2. Aher KB, Bhavar GB, Joshi HP. Rapid RP-HPLC method for quantitative determination of lornoxicam in bulk and pharmaceutical formulations. Int J Chem Tech Res. 2011;3:1220-1224.

3. Bendale AR, Makwana JJ, Narkhede SP, Narkhede SB, Jadhav AG, Vidyasagar G. Analytical method development and validation protocol for Lornoxicam in tablet dosage form. JOCPR. 2011;3:258-263.

4. Bhupendra S, Geetanjali S, Devendra NNS, Saumendu DR, Nishant G. Estimation of lornoxicam in tablet dosage form by uv spectrophotometricmethod. Int J Pharm Sci Res. 2011;2:102-106.

5. Darak VR, Karadi AB, Appalraju A, Appalraju S. Development and Validation of Visible Spectrophotometric methods for the Estimation of Mesalamine in Pharmaceutical Dosage Forms. Der Pharma Chemica. 2011;3:342-346.

6. Gatkal SH, Mhatre PR, Chopade VV, Chaudhari. Development and validation of stability indicating HPLC assay method for determination of mesalamine in bulk drug and tablet formulation. Int. J Pharm Sci Rev Res. 2013;4:401-406.

7. Gurupadayya BM, Navya Sloka S, Aswani Kumar Ch. J. Pharm. Res. 2011;4:39-41.

8. Hanumantha Rao K, Lakshmana Rao A, Chandra Sekhar KB. Validated rp-hplc method for the estimation of mesalamine in bulk and tablet dosage form. IJRPC 2013;3:472-476. 
9. Moharana AK, Banerjee M, Panda S, Muduli JN. Development and validation of uv spectrophotometric method for the determination of mesalamine in bulk and tablet formulation. Int $\mathrm{J}$ Pharm Sci. 2011;3:19-21.

10. Patel KM, Patel CN, Panigrahi B, Parikh AS, Patel HN. Development and Validation of Spectrophotometric Methods for the Estimation of Mesalamine in Tablet Dosage Forms. Young J Pharm. 2010;2:284288.

11. Purushotham Reddy M, Prabhavathi K, Rami Reddy N, Raveendra Reddy P. Two simple spectrophotometric methods for the estimation of mesalamine in bulk sample and its pharmaceutical dosage forms. Global J. Pharmacology. 2011;5:101-105.

12. Rakesh KS, Pankaj SP, Pragya G. Int J Pharm Sci Res. 2010;1:4449.

13. Sivarami Reddy K, Ramachandra B, Naidu NVS. Int. J. Scientific Eng Res. 2014;2:52-56.

14. Narala SR, Saraswathi K. Development and validation of spectrophotometric methods for the estimation of mesalamine in pharmaceutical preparations. J Chem Pharm Res. 2011;3:784-787.
15. Trivedi Rakshit K, Patel Mukesh C, Kharkar Amit. E-J. Chemistry. 2010;8:131-148.

16. Venumadhav E, NeehaT, Bhargavi P, Amreen N, Swetha A, Devala Rao G. Int J Appli Bio Pharm Tech. 2011;2:23-26.

17. Venumadhav E, Neeha T, Bhargav P, Amreen N, Swetha A, Devala Rao G. Int J Pharm Bio Sci. 2010;1:491-494.

18. Moharana AK, Banerjee M, Panda S, Muduli JN., Development and validation of UV spectrophotometric method for the determination of mesalamine in bulk and tablet formulation. Asian J Pharm Clinical Res. 2011;4:71-73.

19. Balram S, Firoz K, Anil B, Sanjay S. Pharmacophore. 2011;2:239243.

20. Ramya Krishna N, Ramanjaneyulu KV, Deepti M, Kiranmayi A, Sudhakar Babu MS, Venkateswara Rao P, Pramod N. Int J Pharm Bio Archives. 2012;3:1012-1016.

21. $\mathrm{ICH}$, International Conference on Harmonization. Validation of Analytical Procedures: text and methodology Q2 (R1). Harmonized Tripartite Guideline. 2005. 